\title{
In vitro selection of yellow passion fruit genotypes for resistance to Fusarium vascular wilt
}

\author{
Patrícia Silva Flores • Wagner Campos Otoni • Onkar Dev Dhingra • \\ Sérgio Paulo Severo de Souza Diniz - Telma Miranda dos Santos • \\ Claudio Horst Bruckner
}

Received: 23 November 2010/ Accepted: 20 June 2011/Published online: 4 August 2011

(C) Springer Science+Business Media B.V. 2011

\begin{abstract}
Fusarium vascular wilt (caused by Fusarium oxysporum f. sp. passiflorae) is a limiting factor in the cultivation of yellow passion fruit (Passiflora edulis). Since there is no effective and economically viable control available, development of resistant or at least tolerant cultivars are in demand. A number of procedures have been used for the initial selection of plant genotypes resistant to various fungal pathogens by means of a fungal culture filtrate or purified toxin. In this study, seeds and in vitro-grown plantlets of passion fruit were screened with different concentrations of either Fusarium oxysporum f. sp. passiflorae (FOP) culture filtrate $(0,20,30,40$ or $50 \%, \mathrm{v} / \mathrm{v})$ or fusaric acid $(0.10,0.20$, 0.30 or $0.40 \mathrm{mM}$ ) supplemented in Murashige and Skoog (MS) basal media. Subsequently, selected plants were inoculated with a conidial suspension of FOP to assess correlation between in vivo and in vitro responses. In vitro sensitivity to the selective agents and the resistance response to the pathogen were also compared. Root growth was markedly influenced by FA, culture filtrate, and conidial
\end{abstract}

P. S. Flores $(\bowtie) \cdot$ T. M. d. Santos · C. H. Bruckner Centro de Pesquisa Agroflorestal Acre, Empresa Brasileira de Pesquisa Agropecuária, Embrapa, Rodovia BR-364, km 14, Caixa Postal, 32169908-970 Rio Branco, AC, Brazil

e-mail: patricia.flores@cpafac.embrapa.br

W. C. Otoni

Departamento de Biologia Vegetal, Universidade Federal de Viçosa, Viçosa, Brazil

O. D. Dhingra

Departamento de Fitopatologia, Universidade Federal de Viçosa, Viçosa, Brazil

S. P. S. de Souza Diniz

Centro de Ciências Biológicas, Departamento de Bioquímica, Universidade Estadual de Maringá, 87029-900 Maringá, PR, Brazil suspension culture treatments. Observations indicated that roots were primary targets for attack by $F$. oxysporum. Successful in vitro selection of resistant genotypes by both FA and culture filtrate treatments suggested that this strategy was viable for accelerating breeding of passion fruit for resistance to the Fusarium vascular wilt.

Keywords Fusarium oxysporum f. sp. passiflorae . Passiflora edulis · Fusaric acid · Culture filtrate .

Tissue culture

\section{Introduction}

Passion fruit belongs to the genus Passiflora, and this genus has nearly 400 known species that are mostly found in tropical regions of the American continent, of which 120 species are native to Brazil (Bernacci et al. 2008). Many of these species are edible; howevwe, Passiflora edulis Sims (sour passion fruit) is the primary cultivated species. Other cultivated species include sweet passion fruit $(P$. alata Curtis), breath passion fruit ( $P$. nitida Kunth), and shark passion fruit ( $P$. cincinnata Mast.) (Zerbini et al. 2008).

$P$. edulis is allogamous, self-incompatible, and has a relatively short history of domestication. For these reasons it is highly variable and has a high genetic improvement potential. Many breeding programs are targeting passion fruit, and have three main objectives when developing cultivars: (i) yield, including a short juvenile period and self-compatibility; (ii) fruit quality, including uniform ripening; and (iii) disease resistance. Of these three, the development of disease resistant cultivars has been the least successful and is the one for which biotechnology holds the greatest potential (Vieira and Carneiro 2004; Zerbini et al. 2008). 
Passion fruit cultivation is hindered by some diseases caused by fungal and bacterial pathogens of which vascular wilt, caused by Fusarium oxysporum Schl. f. sp. passiflo$r a e$, is very significant. This pathogen kills plants causing substantial crop losses and survives for long periods of time in soil, making cultivation of passion fruit unfeasible for years in contaminated areas (Liberato and Costa 2001; Viana et al. 2003). In addition, controlling this disease is very difficult. Chemical treatments are less effective because the fungi are able to rapidly re-colonize in the soil (Ploetz 2006). The disease manifestation occurs in adult plants and is greatly influenced by soil, climate and pathogen interactions (Predieri 2001). Currently, cultural practices, disease-free plant material and resistant cultivars are the main control strategies (Viana and Costa 2003).

Thus, successful long-term cultivation of $P$. edulis warrants development of resistant or tolerant cultivars. Although species, such as $P$. giberti, $P$. nitida, P. macrocarpa, $P$. quadrangularis, $P$. setacea, $P$. alata and $P$. caerulea, are naturally resistant to this disease (Junqueira et al. 2005), introgression of resistance genes to $P$. edulis is difficult because interspecific hybrids frequently have poor development and flowering and are generally sterile (Vieira and Carneiro 2004; Zerbini et al. 2008).

Tissue culture has emerged as a feasible tool for developing plants tolerant to both the biotic (Girhepuje and Shinde 2011; Thomas et al. 2011) and the abiotic stresses (Gao et al. 2010; He et al. 2010; Jin et al. 2010; Qiao et al. 2010; Sorkheh et al. 2011; Subramanyam et al. 2011; Wei et al. 2011).

Plant tissue cultures treated with toxins from pathogenic organisms are useful for studies of plant pathogen interaction as well as for improving the disease resistance of crop plants. In vitro selection can be used with cultures derived from somatic tissues, cell suspension cultures, microspores or anther cultures (Jan et al. 1993). In the later case, selection can be advantageous since resistant plants can be selected during initial growth stages employing toxins as in vitro selective agents, which drastically reduces the number of selection cycles made by crop improvement programs (Ravikumar et al. 2007). Sometimes, a high correlation between in vitro and in vivo resistance to pathogenic fungi has been found by the regeneration capability of calli in the presence of culture filtrates (Thakur et al. 2002; Kumar et al. 2008).

The application of metabolites with various levels of toxicity, during in vitro selection for resistance, has some advantages when compared with natural conditions. The in vitro selection allows the use of large cell populations or physiologically uniform tissues under controlled environmental conditions (Lebeda and Švábová 2010). Such techniques have been used for other species to select genotypes resistant to Fusarium (Lebeda and Švábová 2010).

The present study was done to evaluate the feasibility of employing in vitro methods to select wilt resistant $P$. edulis plants using fusaric acid (FA) and the cell-free culture filtrate of $F$. oxysporum f. sp. passiflorae.

\section{Materials and methods}

Under aseptic conditions, in a laminar flow chamber, the seeds were surface sterilized by immersion in a $70 \%(\mathrm{v} / \mathrm{v})$ ethanol solution, followed by $20 \mathrm{~min}$ in a sodium hypochlorite solution (with $2 \%$ active chlorine), and then rinsed three times with sterilized distilled water. The seeds were scarified by making an incision in the distal part of the seed with the aid of a scalpel. Following this, the scarified seeds were transferred to Petri dishes $(90 \times 15 \mathrm{~mm}$; J. Prolab, Brazil) containing $30 \mathrm{~mL}$ of the culture medium, which was composed of basal MS salts (Murashige and Skoog 1962), $100 \mathrm{mg} \mathrm{l}^{-1}$ myo-inositol, $1.0 \mathrm{mg} \mathrm{l}^{-1}$ thiamine- $\mathrm{HCl}$, $0.05 \mathrm{mg}^{-1}$ pyridoxine- $\mathrm{HCl}, 0.05 \mathrm{mg} \mathrm{l}^{-1}$ nicotinic acid, $2.0 \mathrm{mg}^{-1}$ glycine, $8 \mathrm{~g} \mathrm{l}^{-1}$ agar (Merck, Germany), and supplemented with $0.10,0.20,0.30$ or $0.40 \mathrm{mM}$ of fusaric acid (FA) (Sigma Co). The $\mathrm{pH}$ of the medium was adjusted to 5.7 before autoclaving. Plates were sealed with PVC film (Goodyear, São Paulo, Brazil).

To promote germination, the seeds were incubated for 30 days in a growth room at $27 \pm 2^{\circ} \mathrm{C}$ under a 16-h photoperiod (fluorescent light at $32 \mu \mathrm{mol} \mathrm{m} \mathrm{m}^{-2} \mathrm{~s}^{-1}$ irradiance). Seeds were considered germinated when the radicle and cotyledons were visible. The seeds that did not germinate in the medium containing the lowest FA concentration $(0.10 \mathrm{mM})$ were considered sensitive, whereas those producing seedlings at the highest concentration $(0.40 \mathrm{mM})$ were considered non-sensitive genotypes.

The experiment was conducted in a completely randomized design with five replications, each represented by one culture plate containing six seeds, for each treatment. The prerequisites for the parametric test were verified before statistical analyses. The germination percentage (G) was transformed to $\log 10(\mathrm{G}+1)$. Regression analyses were performed using SAEG, version 9.1 (SAEG 2007).

Response of selected sensitive and non-sensitive genotypes to concentrations of fusaric acid (FA)

The non-germinated seeds of the sensitive genotypes were transferred to the MS medium without FA and incubated again for 30 days to allow them to germinate. The seedlings from non-sensitive genotypes were sectioned to obtain nodal stem explants (average $1.5 \mathrm{~cm}$ ) with one axillary bud. The explants were placed in an upright 
orientation with the proximal end in contact with the MS medium, and supplemented with $100 \mathrm{mg} \mathrm{l}^{-1}$ myo-inositol, $1.0 \mathrm{mg} \mathrm{l}^{-1}$ thiamine- $\mathrm{HCl}, 0.05 \mathrm{mg} \mathrm{l}^{-1}$ pyridoxine- $\mathrm{HCl}$, $0.05 \mathrm{mg} \mathrm{l}^{-1}$ nicotinic acid, $2.0 \mathrm{mg}^{-1}$ glycine, $8 \mathrm{~g} \mathrm{l}^{-1}$ agar and $1.0 \mathrm{mg}^{-1}$ 6-benzyladenine (BA). After 60 days, the shoots were separated and transferred to MS medium lacking growth regulators for elongation and rooting. The plants were then transferred to $30 \mathrm{~mL}$ of the MS basal liquid medium containing $0.0,0.10,0.20$ or $0.30 \mathrm{mM} \mathrm{FA}$, which were in $300 \mathrm{~mL}$ Erlenmeyer flasks, and incubated for 15 days at $27 \pm 2{ }^{\circ} \mathrm{C}$ with a 16-h photoperiod $(20 \mathrm{~W}$ fluorescent light, $32 \mu \mathrm{mol} \mathrm{m} \mathrm{m}^{-2} \mathrm{~s}^{-1}$ irradiance). The root system of the plants was cut to standardize the root length to $1 \mathrm{~cm}$. The number of senescent leaves, and the number, length, and fresh and dry matter mass of the roots were recorded.

The experiment followed a completely randomized design with four replications. Each replication was represented by three $300 \mathrm{~mL}$ flasks with two plants each. The data regarding root length and number were transformed to square root $(\mathrm{x}+1)$, and those of fresh and dry matter mass were transformed to square root $(\mathrm{x}+0.5)$ before the data was subjected to regression analysis. The non-sensitive and sensitive genotypes were compared using analysis of variance (Tukey's test, $P<0.05$ ).

\section{Histology of roots of FA-treated seedling}

Seedlings were collected one week after germination, and incubated on MS basal media containing $0.1 \mathrm{mM} \mathrm{FA}$, fixed in FAA50 (5:5:90; formaldehyde: acetic acid: 50\% ethyl alcohol) (Johansen 1940) and embedded in historesin according to Carmello-Guerreiro (1995). Serial longitudinal sections $(6 \mu \mathrm{m})$ were cut with a rotary microtome (RM2155, Leica Microsystems Inc., USA) and stained with toluidine blue ( $\mathrm{pH}$ 3.2) (O'Brien and McCully 1981). Images were taken using a photomicroscope (Olympus AX70TRF, Olympus Optical, Japan) coupled with a digital camera (Spot Insight Color 3.2.0, Diagnostic Instruments Inc., USA).

Toxicity of culture filtrate and FA production

by $F$. oxysporum f. sp. passiflorae

The pathogen was grown on potato-sucrose-agar in culture plates for two weeks at $27 \pm 2{ }^{\circ} \mathrm{C}$ with a 16-h photoperiod. A $1 \mathrm{~cm}$ diameter culture disc was then transferred to a 250-mL Erlenmeyer flask containing $100 \mathrm{~mL}$ of Richard's medium (Agarwal and Hasija 1986) and incubated for 30 days on an orbital shaker at $70 \mathrm{rpm}$. The culture was filtered through four layers of filter paper and the filtrate was centrifuged for $10 \mathrm{~min}$ at $3493 \mathrm{~g}$ to remove most of the mycelia and conidia. All cells from the supernatant were removed by filtering it through a sterile Milipore ${ }^{\circledR}$ membrane filter that had a $0.22-\mu \mathrm{m}$ pore size, and stored at $-5^{\circ} \mathrm{C}$ until use. The concentration of FA in the cell-free culture filtrate was analyzed using High Performance Liquid Chromatography (HPLC) and Thin Layer Chromatography (TLC), according to Bacon et al. (1996) as modified by Diniz et al. (1998).

\section{Phytotoxicity of the cell-free culture filtrate}

Micropropagated plants derived from FA sensitive and non-sensitive genotypes were used to determine the phytotoxicity of the cell-free culture filtrate. To standardize the plant roots, they were trimmed to $1 \mathrm{~cm}$ in length. Following this, the plants were transferred to $300 \mathrm{~mL}$ flasks containing $30 \mathrm{~mL}$ MS liquid medium supplemented with $100 \mathrm{mg} \mathrm{l}^{-1}$ myo-inositol, $1.0 \mathrm{mg}^{-1}$ thiamine- $\mathrm{HCl}$, $0.05 \mathrm{mg}^{-1}$ pyridoxine- $\mathrm{HCl}, 0.05 \mathrm{mg} \mathrm{l}^{-1}$ nicotinic acid, $2.0 \mathrm{mg} \mathrm{l}^{-1}$ glycine, $8 \mathrm{~g} \mathrm{l}^{-1}$ agar, and $0,20,30,40$ or $50 \%$ $(\mathrm{v} / \mathrm{v})$ of the culture filtrate. The plants were incubated at $27 \pm 2{ }^{\circ} \mathrm{C}$ and a 16 -h photoperiod $\left(32 \mu \mathrm{mol} \mathrm{m} \mathrm{m}^{-2} \mathrm{~s}^{-1}\right.$ irradiance). After 15 days of incubation, the number of senescent leaves, number of roots, root length and the fresh and dry matter masses of the roots were recorded.

The experiment was done using a completely randomized design, with five replications, represented by three flasks with two plants each. When necessary, the data were transformed into square root values $(x+1)$ before being subjected to regression analysis.

\section{Reaction of genotypes to inoculation by $F$. oxysporum f. sp. passiflorae}

The FA-sensitive and non-sensitive plants were allowed to grow for 15 days in a moist chamber and were then transplanted to Magenta boxes (Sigma Chem Co.) containing washed and autoclaved sand $(1.1 \mathrm{~atm}, 30 \mathrm{~min}$ at $121^{\circ} \mathrm{C}$ ) that was moistened with $100 \mathrm{~mL}$ of half strength MS basal salt solution. After seven days in a growth chamber at $27 \pm 2^{\circ} \mathrm{C}$ and a 16 -h photoperiod, the plants were inoculated with the conidial suspension of $F$. oxysporum f. sp. passiflorae. The conidia were obtained by washing the fungal colonies that were growing on potato-sucrose agar. After 30 days, the percentage of surviving plants, the root length, and the fresh and dry root mass were recorded. The experiment followed a completely randomized block design with five replications of five plants each. To compare fresh and dry root mass, data from ten plants from each treatment were averaged and subjected to a t-test. The data analysis was performed using SAEG 9.1. 


\section{Results}

Effect of FA on seed germination

Seed germination decreased significantly $\left(R^{2}=0.71\right)$ as the FA concentration increased in the medium (Fig. 1); however, none of the tested FA concentrations completely inhibited seed germination. The mean germination percentage of about $80 \%$, reached at $0.1 \mathrm{mM} \mathrm{FA}$, decreased to less than $50 \%$ at $0.4 \mathrm{mM}$ FA. The estimated FA concentration for $50 \%$ germination reduction was $0.23 \mathrm{mM}$ (Fig. 1). Most of the seeds that failed to germinate in the presence of FA germinated normally after 30 days upon transfer to medium lacking FA. The seeds that did not germinate in $0.1 \mathrm{mM} \mathrm{FA}$, and those that germinated 0.4 mM FA, were classified as FA-sensitive and non-sensitive genotypes, respectively.

\section{Effect of FA on seedlings growth}

Percentages of senescent leaves and development of the roots of the seedlings growing in FA supplemented medium are summarized in Table 1. The percentage of senescent leaves was significantly lower in the non-sensitive

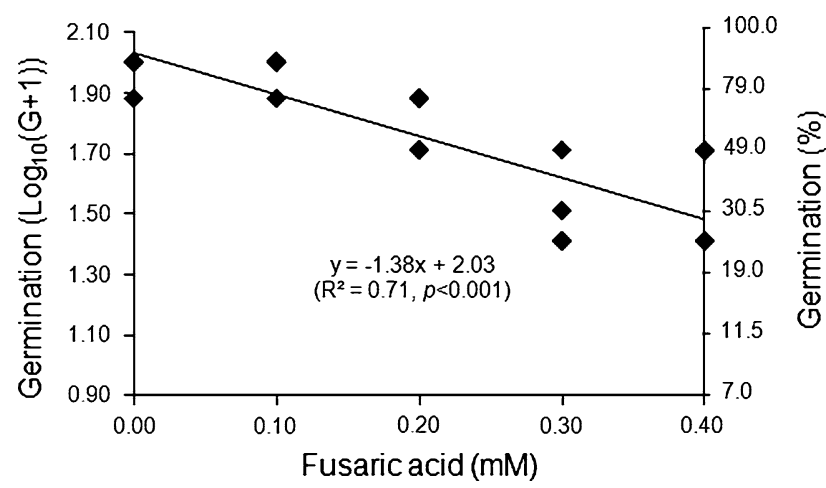

Fig. 1 In vitro germination of Passiflora edulis seeds affected by concentrations of fusaric acid

Table 1 Effect of fusaric acid on passion fruit (Passiflora edulis), after 15 days in culture medium

\begin{tabular}{|c|c|c|c|c|c|}
\hline \multirow[t]{2}{*}{ Genotype } & \multirow{2}{*}{$\begin{array}{l}\text { Senescent } \\
\text { leaves }(\%)\end{array}$} & \multicolumn{4}{|l|}{ Root } \\
\hline & & Number & $\begin{array}{l}\text { Length } \\
(\mathrm{cm})\end{array}$ & $\begin{array}{l}\text { Fresh } \\
\text { mass } \\
(\mathrm{mg})\end{array}$ & $\begin{array}{l}\text { Dry } \\
\text { mass } \\
(\mathrm{mg})\end{array}$ \\
\hline Sensitive & $59.44 \mathrm{a}$ & $4.41 \mathrm{~b}$ & $7.48 b$ & $58.17 \mathrm{~b}$ & $4.84 \mathrm{~b}$ \\
\hline Insensitive & $35.82 \mathrm{~b}$ & $8.16 \mathrm{a}$ & $9.33 \mathrm{a}$ & $188.47 \mathrm{a}$ & $16.02 \mathrm{a}$ \\
\hline
\end{tabular}

Means followed by same letter in the rows do not differ among themselves by Tukey's test at $5 \%$
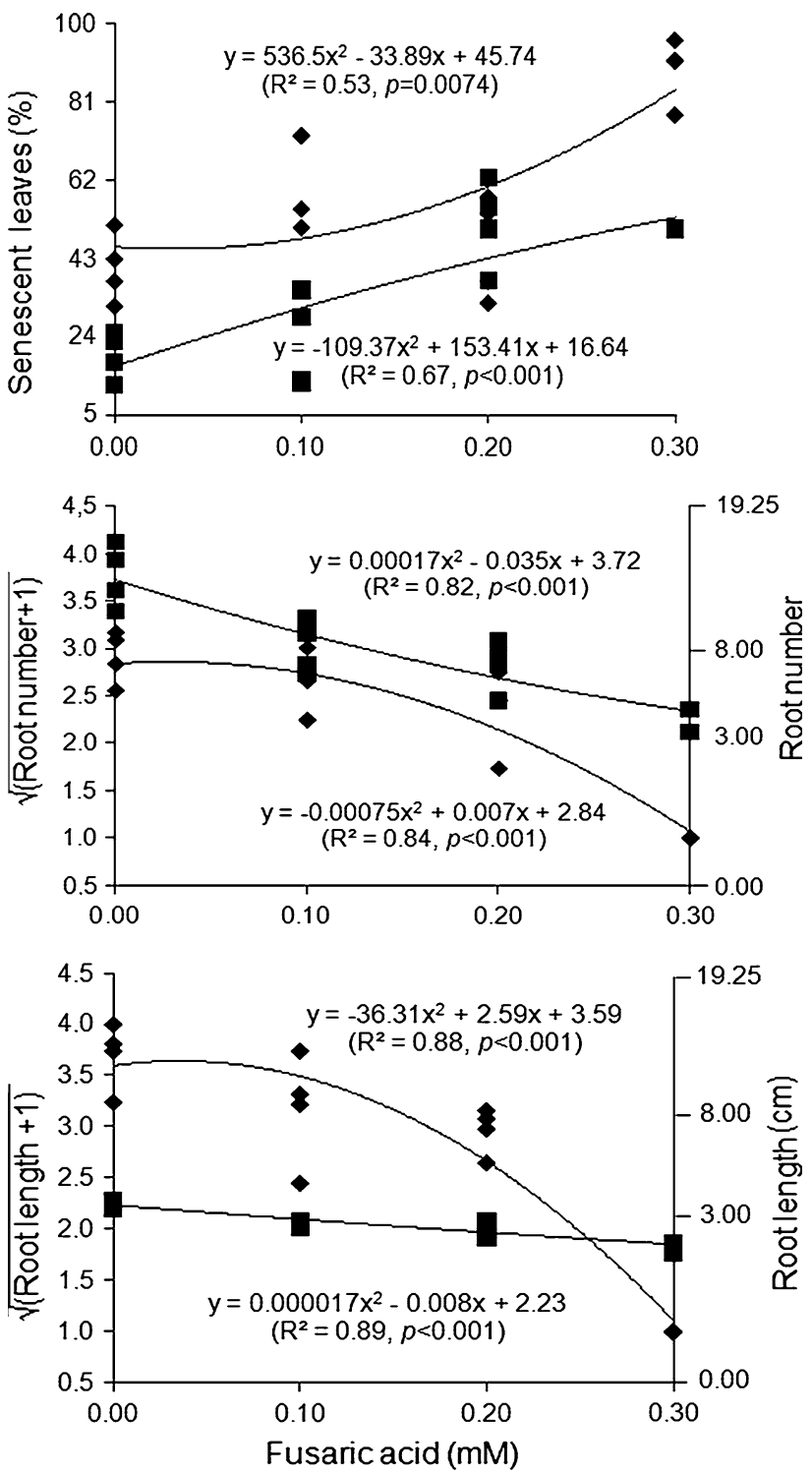

Non-sensitive genotype $\diamond$ Sensitive genotype

Fig. 2 Leaf senescence and root number and length of in vitro seedderived passion fruit (Passiflora edulis) plantlets that were affected by concentrations of fusaric acid

genotype growing in FA amended medium (Fig. 2). At the highest FA concentration assayed $(0.30 \mathrm{mM})$, only $52 \%$ of the leaves were senescent in the non-sensitive genotypes compared to $83 \%$ in the sensitive genotypes (Fig. 2). The root development of the sensitive genotypes was completely inhibited for the plants growing on the medium supplemented with $0.30 \mathrm{mM}$ of FA, whereas an average 4.25 roots per seedling was observed in the non-sensitive genotypes at the same FA concentration (Fig. 2). Similarly, the root length and its fresh and dry mass were less affected in the non-sensitive genotypes when compared to the sensitive genotypes (Fig. 2 and Table 1). 
Fig. 3 Longitudinal section of the primary root of seed-derived passion fruit (Passiflora edulis) plantlet in MS (a) and MS

$0.10 \mathrm{mM}$ of fusaric acid (b and

c). $\mathrm{rc}=$ root cap;

$\mathrm{m}=$ meristematic zone;

$\mathrm{lr}=$ lateral root;

$\mathrm{v}=$ vasculature. Bar $=100 \mu \mathrm{m}$
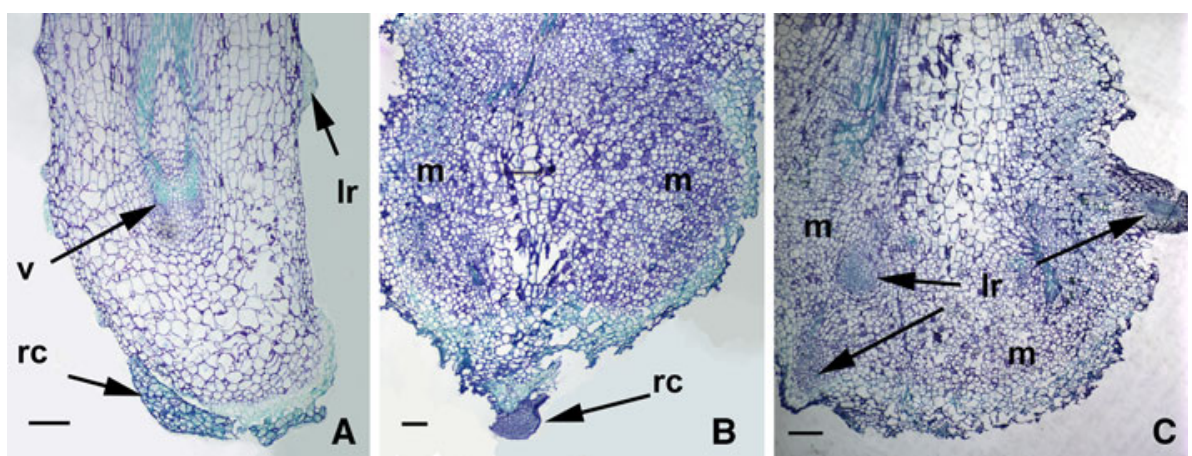

Histological analysis of seedlings germinated in culture media containing different concentrations of FA

Seeds that germinated in the presence of FA produced seedlings with swollen hypocotyl tissue, near the root collar, and a large number of lateral roots (Fig. 3). Intense meristematic activity was observed in the cells located at the elongation zone (Fig. 3b, c), which contributed to the increased root diameter.

In the primary roots of the seedlings produced in FAfree medium, the meristematic activity was restricted to the region just above the root cap (Fig. 3a). The root apices and root cap of the seedlings in FA-amended medium showed a disorganized pattern of cell division (Fig. 3b). Interestingly, the intense meristematic activity was followed by the differentiation of a large number of lateral roots near to the root apex (Fig. 3c).

Phytotoxicity of the culture filtrate

The presence of FA in the culture filtrate $F$. oxysporum $\mathrm{f}$. sp. passiflorae was confirmed by the TCL (Rf 0.83) and HPLC $(1 \mathrm{mM})$ analyses. All seedlings, independent of their sensitivity, were affected by the culture filtrate (Figs. 4 and 5). The toxic effect of the culture filtrate on plants increased with increasing filtrate concentrations. However, the effect of the culture filtrate differed in the FA-sensitive and non-sensitive genotypes. The culture filtrate strongly affected the root growth of the sensitive genotypes (Figs. 4 and 5; Table 2). The root number of sensitive and nonsensitive genotypes reached maximum values at culture filtrate concentrations of 5 and 14\%, respectively.

Reaction of genotypes to inoculation with $F$. oxysporum f. sp. passiflorae

Except for the percent of plant survival, the reaction of sensitive and non-sensitive genotypes differed significantly when inoculated with the pathogen (Fig. 6; Table 3). The effect was pronounced on root development. Root length and the fresh and dry mass of the roots of the non-sensitive
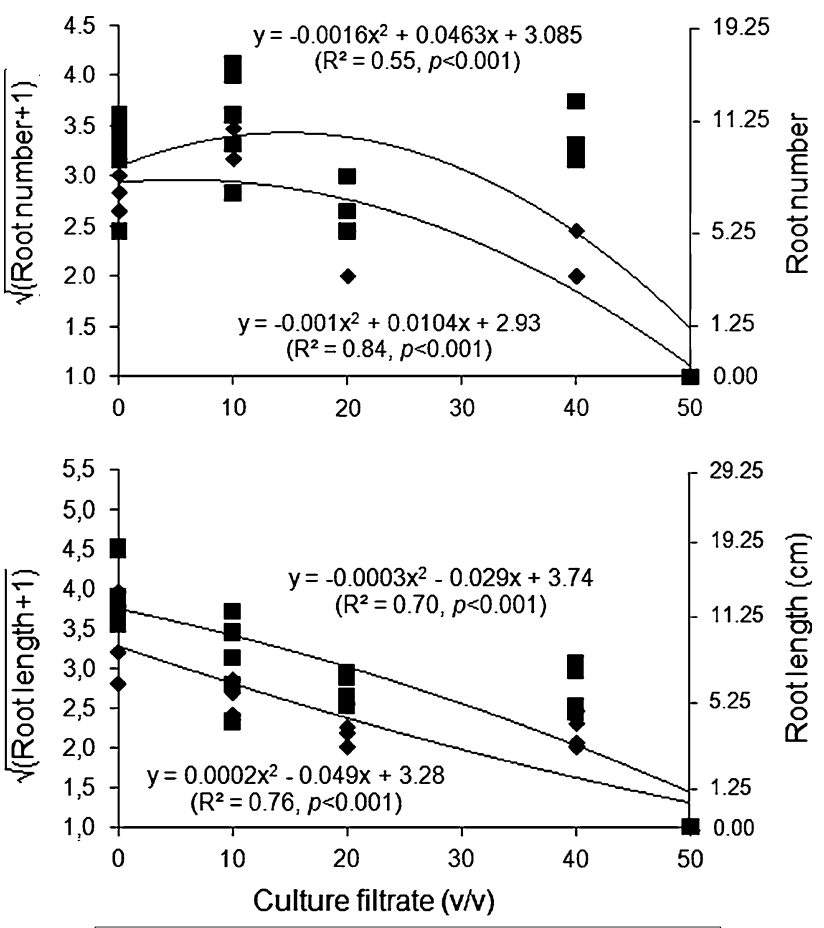

- Non-sensitive genotype $\diamond$ Sensitive genotype

Fig. 4 Effect of the Fusarium oxysporum f. sp. passiflorae filtrate on in vitro root development of passion fruit (Passiflora edulis)

genotypes were significantly higher than those of the sensitive ones (Fig. 6; Table 3).

\section{Discussion}

This study reports the first attempt to assess the potential of using FA and a culture filtrate of Fusarium oxysporum $\mathrm{f}$. sp. passiflorae for in vitro selection of yellow passion fruit (P. edulis) cultivars that are resistant to Fusarium vascular wilt. The data demonstrate that this method of in vitro selection is feasible for screening large populations of the genotypes of this species for resistance to this pathogen. The results show the successful separation of resistant and susceptible genotypes using FA or the culture filtrate. Some 


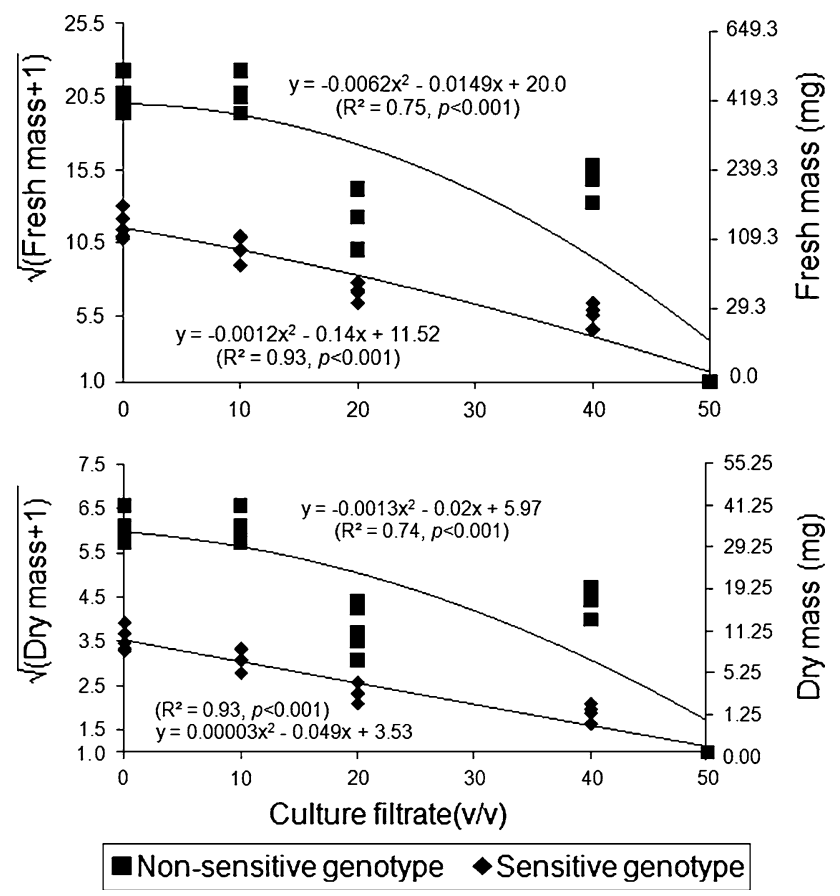

Fig. 5 Effect of the Fusarium oxysporum f. sp. passiflorae filtrate on the fresh and dry mass of roots of passion fruit (Passiflora edulis) in vitro

Table 2 Effects of the $F$. oxysporum $\mathrm{f}$. sp. passiflorae culture filtrate on genotypes of Passiflora edulis in vitro (average of all the treatments)

\begin{tabular}{lllll}
\hline Genotype & Root & & & \\
\cline { 2 - 5 } & Number & $\begin{array}{l}\text { Length } \\
(\mathrm{cm})\end{array}$ & $\begin{array}{l}\text { Fresh mass } \\
(\mathrm{mg})\end{array}$ & $\begin{array}{l}\text { Dry mass } \\
(\mathrm{mg})\end{array}$ \\
\hline Sensitive & $5.00 \mathrm{~b}$ & $1.63 \mathrm{~b}$ & $32.16 \mathrm{~b}$ & $2.73 \mathrm{~b}$ \\
Insensitive & $7.56 \mathrm{a}$ & $1.87 \mathrm{a}$ & $49.36 \mathrm{a}$ & $4.18 \mathrm{a}$ \\
\hline
\end{tabular}

Means followed by same letter in the rows do not differ among themselves by Tukey's test at $5 \%$
Table 3 Effects of the inoculation with $F$. oxysporum f. sp. passiflorae on passion fruit (Passiflora edulis)

\begin{tabular}{lllll}
\hline Genotype & $\begin{array}{l}\text { Plant } \\
\text { survival }(\%)\end{array}$ & $\begin{array}{l}\text { Root length } \\
(\mathrm{cm})\end{array}$ & $\begin{array}{l}\text { Fresh mass } \\
(\mathrm{mg})\end{array}$ & $\begin{array}{l}\text { Dry mass } \\
(\mathrm{mg})\end{array}$ \\
\hline Insensitive & $56.0 \mathrm{a}$ & $6.80 \mathrm{a}$ & $278.0 \mathrm{a}$ & $83.4 \mathrm{a}$ \\
Sensitive & $52.0 \mathrm{a}$ & $3.93 \mathrm{~b}$ & $122.0 \mathrm{~b}$ & $15.86 \mathrm{~b}$ \\
\hline
\end{tabular}

Means followed by same letter in the rows do not differ among themselves by Tukey's test at 5\% (for plant survival and root length) or by $T$ test (for fresh and dry mass)

authors doubt the stability of resistance of plants derived from in vitro selection based on the use of a purified toxin or culture filtrate. Remotti et al. (1997) argued that the use of a purified toxin is a more appropriate selective agent, because culture filtrates are known to contain other phytotoxic compounds, which can led to the selection of plants resistant to other factors instead of the target pathogen. On the other hand, because FA is known to be a non-selective toxin, it is possible that other components present in the culture filtrate are necessary for it to be selective (Borrás and Bermúdez 2010).

It was possible to distinguish resistant and susceptible genotypes of passion fruit through in vitro selection of seeds and seedlings using FA as the sole selective agent, and a culture filtrate of $F$. oxysporum f. sp. passiflorae confirmed the reaction of genotypes to the FA. Comparing the response between in vitro selected agents and plants inoculated with the pathogen is essential to evaluate and confirm the in vitro selected genotypes, since a plants reaction to an inoculation with the pathogen is more reliable. This is because the plants are grown in a setting that more closely resembles actual field conditions, allowing for a complete plant-pathogen interaction (Predieri 2001). A strong correlation between in vitro selection and in vivo resistance in other host-parasite interactions has been reported (Thakur et al. 2002; Kumar et al. 2008; Wilson

Fig. 6 Passion fruit (Passiflora edulis) plants inoculated with the $F$. oxysporum f. sp. passiflorae conidium suspension: a Sensitive plants, b Non-sensitive plants

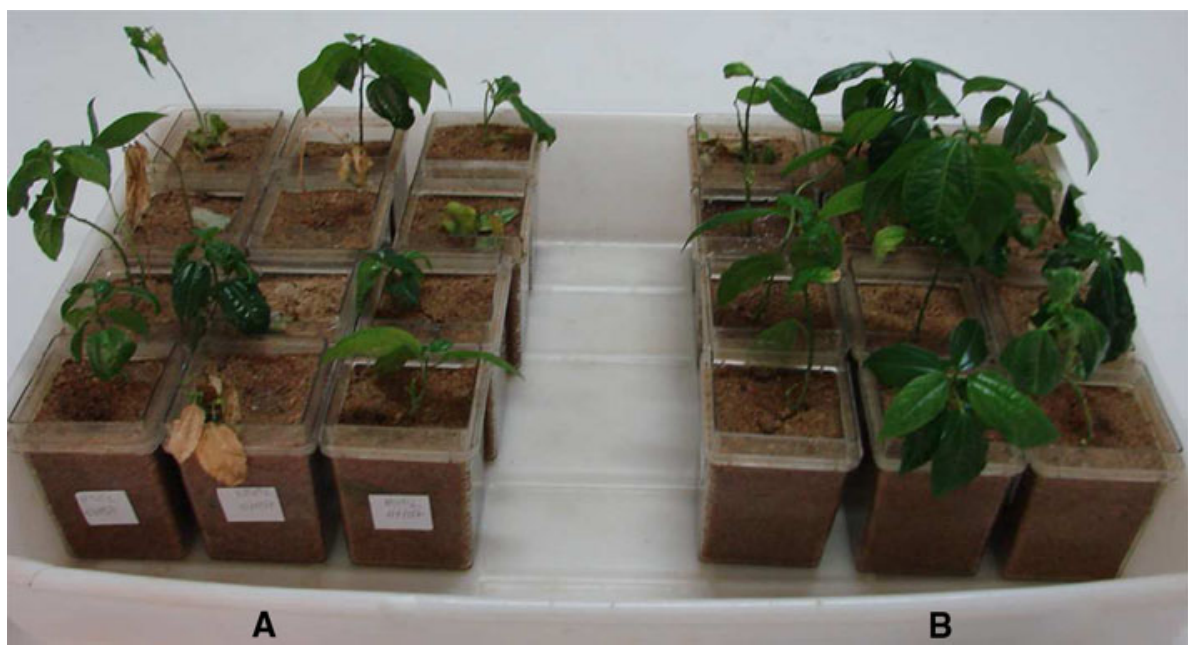


et al. 2010). Concurrently, our data also indicate that the in vitro sensitivity to FA or the culture filtrate, and susceptibility to the pathogen, are highly correlated.

In both sensitive and non-sensitive genotypes, increasing the concentrations of FA or the culture filtrate increased the intensity of the response, which was measured by seed germination, root length and new root formation, and dry and fresh root mass. During disease development, the pathogen produces toxins in concentrations lower than those usually produced in the culture medium, due to highly favorable conditions for fungal growth and the nutritional composition of the medium (Matsumoto et al. 2010). FA is produced by several species of Fusarium and it is a non-specific toxin, which causes wilt symptoms in different plants species (Matsumoto et al. 2010). Curir et al. (2000) reported that FA concentrations above $1 \mathrm{mM}$ inhibited polyphenol oxidase activity in Fusarium wilt in susceptible or resistant cultivars of lily; however, only traces of FA were detected in the infected tissues (Curir et al. 2000). Possibly, the addition of high doses of FA or culture filtrate to the medium provided more toxins than those produced by the pathogen in the tissues of insensitive passion fruit plants grown under natural conditions, which caused an inhibitory effect.

For the sensitive inoculated plants, the low numbers observed for root length and fresh and dry mass of the roots, confirms that the roots are the primary target sites of the fungus. The development of the root system was markedly affected by both FA and the culture filtrate in the in vitro experiments. Other studies have reported similar effects (Telles-Pupulin et al. 1996; Haikal 2008). Root darkening, although not quantified in the present work, was observed in plants inoculated with the pathogen, which was similar to the symptoms observed in the field, and was more frequent in the FA-sensitive plants. According to Bouizgarne et al. (2006), high concentrations of FA can alter membrane permeability and mitochondrial activity, resulting in the inhibition of ATP synthesis. Telles-Pupulin et al. (1996) attributed reduced root growth of FA treated maize to the inhibitory effect on the mitochondrial respiration and consequent reduction of the supply of ATP. Cell respiration is very important for seed germination, and occurs at a much higher rate than in any other physiological process. Thus, the FA induced inhibition of seed germination may be related to the decreased respiration activity in the tissues. Our data indicated that FA was not lethal to the seeds, since most of them germinated when transferred to the FA-free medium. In addition, it had an inhibitory effect on seed germination at concentrations similar to that for root growth inhibition.

In the present work, the FA treatment changed the root anatomy, as reported for maize roots by Diniz and Oliveira (2009). These authors attributed the shortening of the root elongation zone and increased root diameter to the acceleration of cell differentiation in response to FA, which led to an increase in the number of cell layers and cell diameter. Siqueira (1963) reported that plants infected by wilt caused by fungi show growth alterations, such as hyperplasia of the parenchyma near the infected vascular tissues and formation of several adventitious roots. Fusicoccin, a phytotoxin produced by Fusioccum amygdale, causes hyperpolarization, proton extrusion and acidification of cell walls, which is similar to symptoms caused by auxins (Moyen et al. 2007). Activation of $\mathrm{H}^{+}$-ATPase resulting in the transient hyperpolarization of the membrane of root cells, an increase of cytosolic calcium, and a modification of ion flux in plant tissues are also induced by FA (Bouizgarne et al. 2006). Therefore, one of the effects of this toxin is a transient stimulus of growth, due to the intense meristematic activity observed in the seedlings treated with FA (Fig. 3).

Selecting genotypes in the field that are resistant to $F$. oxysporum $\mathrm{f}$. sp. passiflorae is not feasible because disease symptoms appear slowly in adult plants and the progress of the disease is affected by the inoculum density and distribution in the field, and environmental conditions. However, our study demonstrates the possibility of distinguishing resistant and susceptible genotypes at a much earlier stage, during seed germination. A large number of genotypes can be evaluated using a small amount of space, time, and resources. Therefore, the results of this study could potentially accelerate the process of breeding passion fruit for resistance to Fusarium vascular wilt. The genotypes selected through this process can now be evaluated under field conditions.

Acknowledgments We are grateful to Dr. F. Laranjeira for providing the isolate of Fusarium oxysporum f. sp. passiflorae. This research was financed by the National Council for Scientific and Technological Development (CNPq, Brazil).

\section{References}

Agarwal GP, Hasija SK (1986) Microorganisms in the laboratory-a laboratory guide of mycology, microbiology and plant pathology. Print House, Lucknow

Bacon CW, Porter JK, Norred WP, Leslie JF (1996) Production of fusaric acid by Fusarium species. Appl Environ Microbiol 62:4039-4043. doi:0099-2240/96/\$04.0010

Bernacci LC, Soares-Scott MD, Junqueira NTV, Passos IRS, Meletti LMM (2008) Passiflora edulis Sims: the correct taxonomic way to cite the yellow passion fruit (and of others colors). Rev Brasil Frutic 30:566-576. doi:10.1590/S0100-29452008000200053

Borrás O, Bermúdez RS (2010) The pineapple-Fusarium subglutinans interaction: an early selection system for disease resistance. In: FAO/IAEA. Mass screening techniques for selecting crops resistant to disease. International Atomic Energy Agency, Vienna, pp 159-172 
Bouizgarne B, El-Maarouf-Bouteau H, Madiona K, Biligui B, Monestiez M, Pennarun AM, Amiar Z, Rona JP, Ouhdouch Y, El Hadrami I, Bouteau F (2006) A putative role for fusaric acid in biocontrol of the parasitic angiosperm Orobanche ramosa. Mol Plant-Microbe Interact 19:550-556. doi:10.1094/MPMI19-0550

Carmello-Guerreiro, SM (1995) Técnica de inclusão de material vegetal em historesina. In: Encontro Regional de Anatomistas do Estado de São Paulo, 1, 1995, Rio Claro. Rio Claro:Unesp cultures. Physiol Plant 15:473-497 (In Portuguese)

Curir P, Guglieri L, Dolci M, Capponi A, Aurino G (2000) Fusaric acid production by Fusarium oxysporum in the lily basal rot disease. Europ J Plant Pathol 106:849-856

Diniz SPSS, Oliveira RC (2009) Effects of fusaric acid on Zea mays L. seedlings. Фyton 78:155-160

Diniz SPSS, Dâcome AS, Bueno MAS, Balleroni CR, Cezini ID, Costa SC (1998) Técnicas em TLC e HPLC para determinação do ácido fusárico em culturas líquidas de Fusarium spp. Fitopatol Brasil 23:280-281 (In Portuguese)

Gao F, Xiong A, Peng R, Jin X, Xu J, Zhu B, Chen J, Yao Q (2010) OsNAC52, a rice NAC transcription factor, potentially responds to ABA and confers drought tolerance in transgenic plants. Plant Cell Tiss Org Cult 106:255-262. doi:10.1007/s11240-0099640-9

Girhepuje PV, Shinde GB (2011) Transgenic tomato plants expressing a wheat endochitinase gene demonstrate enhanced resistance to Fusarium oxysporum f. sp. lycopersici. Plant Cell Tiss Org Cult 105:243-251. doi:10.1007/s11240-010-9859-5

Haikal NZ (2008) Effects of filtrates of pathogenic fungi of soybean on seed germination and seedling parameters. J Appl Sci Res 4:48-52

He C, Yang A, Zhang W, Gao Q, Zhang J (2010) Improved salt tolerance of transgenic wheat by introducing betA gene for glycine betaine synthesis. Plant Cell Tiss Org Cult 101:65-78. doi:10.1007/s11240-009-9665-0

Jan B, Kang FY, Peter Pauls K (1993) In vitro selection for disease/ toxins resistance. In: Dixon RA, Gonzales RA (eds) Plant cell cultures: a practical approach. Oxford University Press, Oxford, pp 87-94

Jin T, Chang Q, Li W, Yin D, Li Z, Wang Deli, Liu B, Liu L (2010) Stress-inducible expression of GmDREB1 conferred salt tolerance in transgenic alfalfa. Plant Cell Tiss Org Cult 100:219-227. doi:10.1007/s11240-009-9628-5

Johansen DA (1940) Plant microtechnique. McGraw-Hill, New York Junqueira NTV, Braga MF, Faleiro FG, Peixoto JR, Bernacci LC (2005) Potencial de espécies silvestres de maracujazeiros como fonte de resistência a doenças. In: Faleiro FG, Junqueira NTV, Braga MF (eds) Maracujá: germoplasma e melhoramento genético. Embrapa, Planaltina, pp 81-108 (In Portuguese)

Kumar S, Kumar S, Negi SP, Kanwar JK (2008) In vitro selection and regeneration of chrysanthemum (Dendranthema grandiflorum Tzelev) plants resistant to culture filtrate of Septoria obesa Syd. In Vitro Cell Dev Biol Plant 44:474-479. doi:10.1007/s11627008-9131-4

Lebeda A, Švábová L (2010) In vitro screening methods for assessing plant disease resistance. In: FAO/IAEA. Mass Screening Techniques for Selecting Crops Resistant to Disease. International Atomic Energy Agency, Vienna, pp 5-45

Liberato JR, Costa H (2001) Doenças fúngicas, bacterianas e fitonematóides. In: Bruckner CH, Picanço MC (eds) Maracujá: tecnologia de produção. pós-colheita, agroindústria, mercado. Cinco Continentes, Porto Alegre, pp 243-326 (In Portuguese)

Matsumoto K, Barbosa ML, Souza LAC, Teixeira JB (2010) In vitro selection for resistance to Fusarium wilt in Banana In: FAO/ IAEA. Mass Screening Techniques for Selecting Crops Resistant to Disease. International Atomic Energy Agency, Vienna, pp 101-109
Moyen C, Bonmort J, Roblin G (2007) Membrane effects of 2, 4-dichlorophenoxyacetic acid in motor cells of Mimosa pudica L. Plant Physiol Biochem 45:420-426. doi:10.1016/j.plaphy. 2007.03.030

Murashige T, Skoog F (1962) A revised medium for rapid growth and bio assays with tobacco tissue cultures. Physiol Plant 15(3): 473-497

O'Brien TP, McCully ME (1981) The study of plant structure principles and selected methods. Termarcarphi Pty, Melbourne

Ploetz RC (2006) Fusarium-induced diseases of tropical, perennial crops. Phytopathol 96:648-652. doi:10.1094/PHYTO-96-0648

Predieri S (2001) Mutation induction and tissue culture in improving fruits. Plant Cell Tiss Org Cult 64:185-210

Qiao G, Zhou J, Jiang J, Sun Y, Pan L, Song H, Jiang J, Zhuo R, Wang X, Sun Z (2010) Transformation of Liquidambar formosana L. via Agrobacterium tumefaciens using a mannose selection system and recovery of salt tolerant lines. Plant Cell Tiss Org Cult 102:163-170. doi:10.1007/s11240-010-9717-5

Ravikumar RL, Patil BS, Soregaon CD, Hegde SG (2007) Genetic evidence for gametophytic selection of wilt resistant alleles in chickpea. Theor Appl Gen 114:619-662. doi:10.1007/s00122006-0462-4

Remotti PC, Löffler HJM, Vloten-Doting L (1997) Selection of cellline and regeneration of plant resistant to fusaric acid from Gladiolus x grandiflorus cv. 'Peter Pear'. Euphytica 96:237-245. doi:10.1023/A:1003034215722

SAEG-Sistema para Análises Estatísticas (2007). Versão 9.1: Fundação Arthur Bernardes-UFV, Viçosa (In Portuguese)

Siqueira L (1963) Growth regulators in the plant disease. Annu Rev Phytopathol 1:5-30

Sorkheh K, Shiran B, Khodambshi M, Rouhi V, Ercisli S (2011) In vitro assay of native Iranian almond species (Prunus L. spp.) for drought tolerance. Plant Cell Tiss Org Cult 105:395-404. doi: 10.1007/s11240-010-9879-1

Subramanyam K, Sailaja KV, Subramanyam K, Rao DM, Lakshmidevi K (2011) Ectopic expression of an osmotin gene leads to enhanced salt tolerance in transgenic chilli pepper (Capsicum annum L.). Plant Cell Tiss Org Cult 105:181-192. doi: 10.1007/s11240-010-9850-1

Telles-Pupulin AR, Diniz SPSS, Bracht A, Ishii-iwamoto EL (1996) Effects of fusaric acid on respiration in maize root mitochondria. Biol Plant 38:421-429

Thakur M, Sharma DR, Sharma SK (2002) In vitro selection and regeneration of carnation (Dianthus caryophyllus L.) plants resistant to culture filtrate of Fusarium oxysporum $\mathrm{f}$. sp. dianthi. Plant Cell Rep 20:825-828. doi: 10.1007/s00299-001-0412-1

Thomas P, Goplakrishnan C, Krishnareddy M (2011) Soft rot inciting Pectobacterium carotovorum (syn. Erwinia carotovora) is unlikely to be transmitted as a latent pathogen in micropropagated banana. Plant Cell Tiss Org Cult 105:423-429. doi:10.1007/ s11240-010-9882-6

Viana FMP, da Costa AF (2003) Doenças do maracujazeiro. In: Freire FCO, Cardoso JE, Viana FMP (eds) Doenças de fruteiras tropicais de interesse agroindustrial. EMBRAPA, Brasília, pp 269-322 (In Portuguese)

Vieira MLC, Carneiro MS (2004) Passiflora spp., passionfruit. In: Litz RE (ed) Biotechnology of fruit and nut crops. CABI Publishing, Oxford, pp 435-453

Wei Q, Guo YJ, Cao HM, Kuai BK (2011) Cloning and characterization of an AtNHX2-like $\mathrm{Na}+/ \mathrm{H}+$ antiporter gene from Ammopiptanthus mongolicus (Leguminosae) and its ectopic expression enhanced drought and salt tolerance in Arabidopsis thaliana. Plant Cell Tiss Org Cult 105:309-316. doi:10.1007/ s11240-010-9869-3

Wilson CR, Tegg RS, Wilson AJ, Luckman GA, Eyles A, Yuan ZQ, Hingston LH, Conner AJ (2010) Stable and extreme resistance to 
common scab of potato obtained through somatic cell selection. Phytopathol 100:460-467. doi:10.1094/PHYTO-100-5-0460 Zerbini FM, Otoni WC, Vieira MLC (2008) Transgenic passionfruit. In: Chittaranjan K, Hall T (eds) A compendium of transgenic crop plants-tropical and subtropical fruits and nuts, 1st edn. Wiley, Berlin, pp 213-234 